BRES 18882

\title{
Glutamate as a neuron-to-glial signal for mitogenesis: role of glial $N$-methyl-D-aspartate receptors
}

\author{
Yasutaka Uchihori and Donald G. Puro \\ Departments of Ophthalmology and Physiology, The University of Michigan, Ann Arbor, NI 48105 (USA)
}

(Accepted 5 January 1993)

Key words: Müller cell; Glia; Retina; Proliferation; N-Methyl-D-aspartate receptor channel; Glutamate

\begin{abstract}
The presence on glial cells of receptors for neurotransmitters suggests the capability of neuron-to-glial signalling. Here, we asked whether the retinal transmitter, glutamate, may serve as a mitogenic signal for human retinal glial cells. Using cultured glia from the adult postmortem retina, we found that glutamate stimulated the proliferation of these glial cells. Pharmacological experiments indicated that this proliferative effect involved activation of $N$-methyl-D-aspartate (NMDA) receptor channels. Activation of NMDA receptors on retinal glial cells may mediate a proliferative response of these cells to pathophysiologic conditions causing a sustained elevation of glutamate.
\end{abstract}

\section{INTRODUCTION}

Glial cells of the retina, as in other parts of the CNS, often proliferate in response to pathological conditions such as ischemia and trauma. The proliferation of glia may be a significant factor in compromising neural function with disease or injury. For example, glial proliferation in the eye appears to be an important cellular event associated with reduced neuronal function caused by detachment of the retina from the underlying retinal pigment epithelium ${ }^{1}$.

Although glial mitogenesis is likely to play a significant role in retinal pathobiology, knowledge concerning the regulation of the proliferative response of retinal glia is limited. In this study we asked whether glutamate, a neurotransmitter for the photoreceptors and bipolar cells ${ }^{21}$, may serve as a mitogen for human retinal glial cells. Glutamate was chosen for study because the extracellular concentration of this transmitter increases in the nervous system under various pathophysiological conditions ${ }^{8,16}$ that can be associated with glial proliferation ${ }^{20,34}$. Direct effects of glutamate on glia appear to be possible, since various types of glial cells have glutamate receptors ${ }^{6}$.

To detect a possible proliferative effect of gluta- mate, we used cultures of glial cells derived from the adult human retina. An advantage of a cell culture system was the ability to quantify a mitogenic effect on human retinal glial cells of glutamate and various of its agonists and antagonists under serum-free conditions in the absence of significant numbers of non-glial cells.

We report that glutamate can stimulate significantly the proliferation of human retinal glial cells in culture. Pharmacological experiments indicate that activation of NMDA ( $N$-methyl-D-aspartate) receptors plays a role in the mitogenic response of the glial cells to glutamate. These findings support the hypothesis that a sustained elevation of glutamate may serve as a signal for the proliferation of glial cells in the retina.

\section{MATERIALS AND METHODS}

\section{Cell culture}

Cultures of retinal glial cells were prepared using modifications ${ }^{28,30}$ of methods developed by others ${ }^{2,25}$. Postmortem eyes from donors aged $39-87$ years were supplied within $24 \mathrm{~h}$ of death by the Michigan Eye Bank. Retinas were removed, exposed to a calciumand magnesium-free phosphate buffer (CMF) supplemented with $0.1 \%$ trypsin ( $3 \times$ crystallized; Worthington), $0.2 \%$ hyaluronidase (Sigma) and $4 \%$ chicken serum (GIBCO) for $45 \mathrm{~min}$ at $37^{\circ} \mathrm{C}$ and then dissociated mechanically in $80 \%$ medium $A \quad(1: 1$ ratio of Dulbecco's modified Eagle's medium and Ham's F12 medium) and 
$20 \%$ fetal bovine serum. Dissociated cells from one retina were added to three 35-mm Petri dishes, kept in a humidified environment of $96.5 \%$ air $/ 3.5 \% \mathrm{CO}_{2}$, at $37^{\circ} \mathrm{C}$ and fed with $80 \%$ medium $\mathrm{A}$ and $20 \%$ fetal bovine serum twice per week. Cultures that reached more than $80 \%$ confluency were split to three $35-\mathrm{mm}$ Petri dishes. Cells that had been in culture for 2-6 passages were used. Cultures of retinal glial cells from 11 donors were assayed; all were sensitive to NMDA.

As reported elsewhere ${ }^{30}$, virtually all of the cells prepared by this method are immunoreactive to a monoclonal antibody specific for retinal Müller cells. Also, the cells in this culture system stain positively with antibodies to glial fibrillary acidic protein ${ }^{30}$, as do Müller glia and astrocytes in the human retina ${ }^{36}$. Fig. 1 shows that the cells in our culture stain positively with polyclonal antibodies against glutamine synthetase. Immunoreactivity for glutamine synthetase is localized in the retina in situ to the Müller glial cells and does not occur in the astrocytes located on the inner surface of the retina ${ }^{19}$. Thus, immunocytochemical markers indicate that the cells in these cultures are Müller cells.

\section{Cell proliferation assays}

Changes in cell number and incorporation of bromodeoxyuridine (BrdU) into glial nuclei were as detailed previously ${ }^{29,30,35}$. In brief, retinal glial cells from a near confluent culture were removed from the dish by exposure for $15 \mathrm{~min}$ to $0.1 \%$ trypsin in CMF, centrifuged and resuspended in $7 \mathrm{ml}$ of $80 \%$ medium $A$ and $20 \%$ fetal bovine serum. Aliquots $(0.15 \mathrm{ml})$ of the cell suspension were placed on $8 \times 8$-mm grids that had been imprinted on the bottoms of $35-\mathrm{mm}$ plastic Petri dishes. The grids, which were imprinted using a template (Mecanex), contained a $26 \times 26$ array of alphabetically labeled squares. The day following addition of the $0.15 \mathrm{ml}$ suspension of cells, $1.5 \mathrm{ml}$ of $80 \%$ medium $\mathrm{A}$ and $20 \%$ fetal bovine serum was added to each dish. On the second day after the initial plating, a baseline cell count was performed for each Petri dish by starting at one corner of the grid and proceeding systemically until at least 100 cells had been counted. Recording the label of the first and last squares of the grid counter permitted recounting of the same area later. After baseline counting, the Petri dishes were washed twice with Dulbecco's modified Eagle's medium and exposed to medium B (medium A plus $50 \mathrm{ug} / \mathrm{ml}$ transferrin and $30 \mathrm{nM}$ sodium selenite) supplemented as needed with various concentrations of $\mathrm{L}$-glutamate (Sigma), NMDA (Sigma), kainate (KA; Sigma), quisqualate (QA; Research Biochemicals, Inc. (RBI)), D-2-amino-5-phosphonovalerate (D-AP5; Sigma), (+)-5-methyl-10,11-dihydro-5H-dibenzo[a,d] cyclohepten-5,10-imine hydrogen maleate (MK-801; RBI) and/or 6cyano-7-nitroquinoxaline-2,3-dione (CNQX; RBI) for 2 days in initial experiments (Fig. 3), for variable times (Fig. 4) or for $6 \mathrm{~h}$ (Figs. 5-9). Medium B contains $43 \mu \mathrm{M}$ glutamate and $250 \mu \mathrm{M}$ glycine.

In some experiments (Table II), medium $C$ or one of its variations (Table I) with or without $500 \mu \mathrm{M}$ NMDA was exposed to the cultures for $4.5 \mathrm{~h}$. In experiments in which the exposure to glutamate agonists and/or antagonists was $<2$ days, the cultures were switched to medium B. Two days after the initial cell counting, cells again were counted over the same areas of the grids as were surveyed for the baseline counts. The percent increase in cell number was then calculated.

In experiments examining the incorporation of BrdU into DNA, cells on grid-stamped dishes were exposed for 2 days to $10 \mu \mathrm{M}$ BrdU in medium $B$ with or without the addition of $1 \mathrm{mM}$ glutamate or 500 $\mu$ M NMDA. BrdU was localized by immunocytochemical methods similar to those used by Yong et al. ${ }^{37}$, except the avidin-biotin-peroxidase method was used here. In brief, cultures were rinsed, then fixed with $70 \%$ ethanol at $-20^{\circ} \mathrm{C}$ for $30 \mathrm{~min}$, exposed to $2 \mathrm{M} \mathrm{HCl}$ for $10 \mathrm{~min}$ to denature the DNA, bathed in $0.1 \mathrm{M}$ sodium borate ( $\mathrm{pH} 9$ )
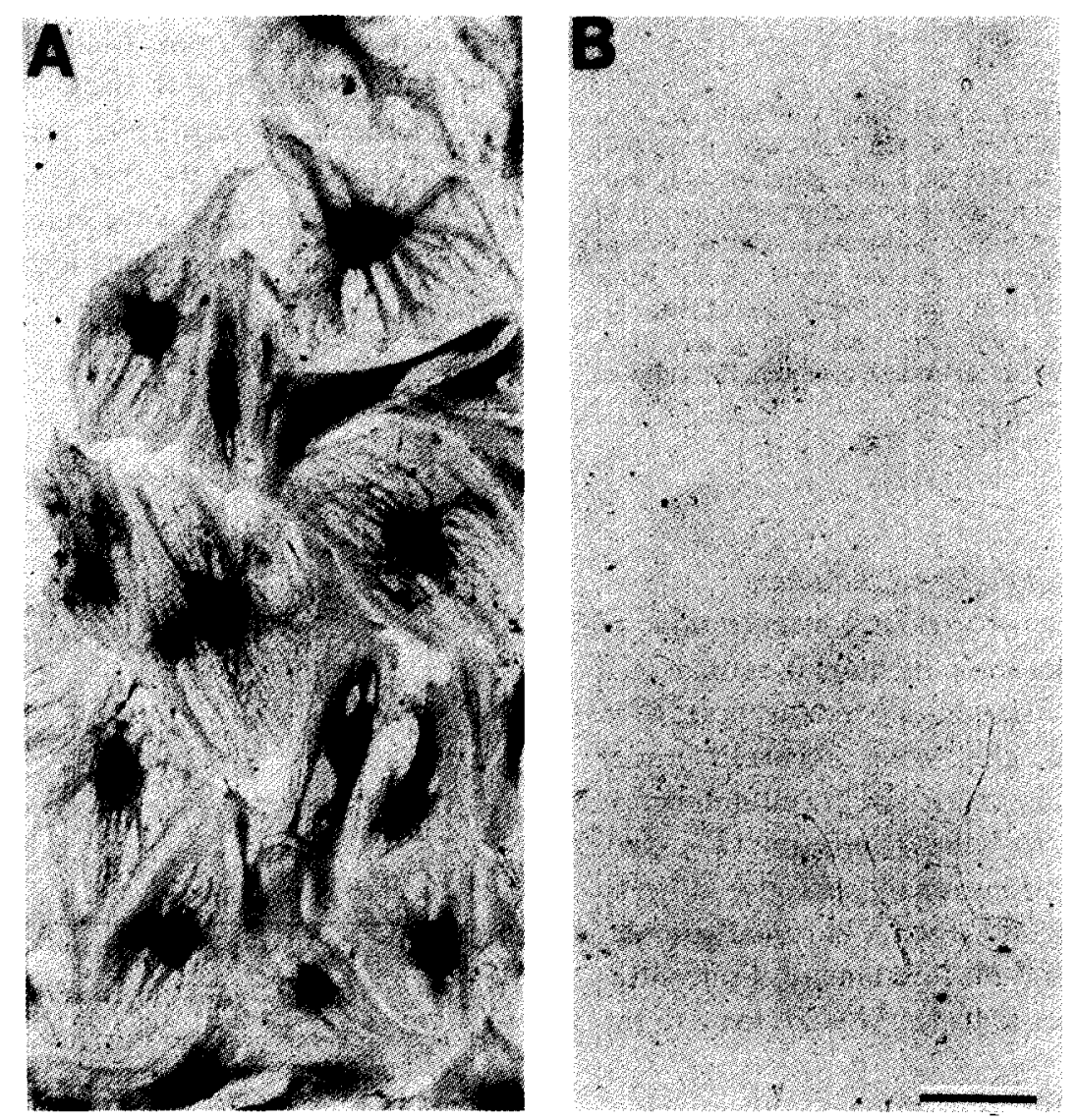

Fig. 1. Cultured cells derived from adult human retina and stained with anti-glutamine synthetase antibodies (A). A diffuse cytoplasmic and nuclear portion of the cells was labeled. This staining pattern is similar to that seen in Müller cells in situ. Immunocytochemistry controls (B) showed minimal label present in the cells. Scale bar represents $100 \mu \mathrm{m}$. 


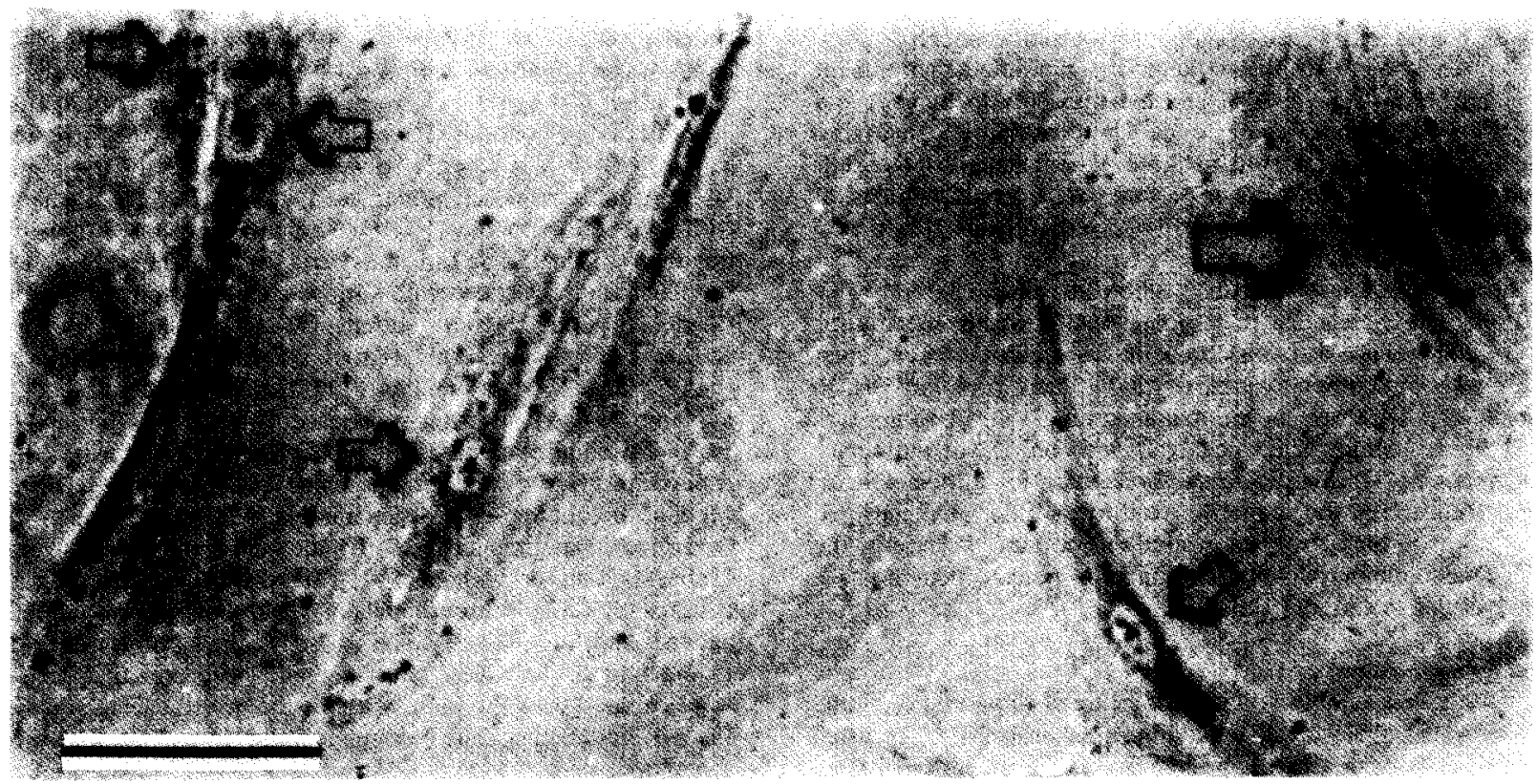

Fig. 2. Cultured retinal glial cells stained with an anti-bromodeoxyuridine antibody. The large arrow points to a cell with a positively labeled nucleus. The smaller arrows show cells with unlabeled nuclei. The scale bar represents $100 \mu \mathrm{m}$.

for $10 \mathrm{~min}$ and then exposed to a monoclonal antibody to BrdU $\left(1: 10\right.$; Becton Dickinson) for $30 \mathrm{~min}$ at $37^{\circ} \mathrm{C}$. Subsequently, the cultures were incubated in biotinylated anti-mouse IgG antibody $(1: 1,000$; Vector) for $30 \mathrm{~min}$ at room temperature, followed by application of the avidin-biotin-peroxidase complex (1:100; Vector) with development in diaminobenzidine. Anti-BrdU staining is illustrated in Fig. 2.

\section{Immunocytochemistry}

Cultures were rinsed in phosphate-buffered saline (PBS), then fixed with $70 \%$ ethanol at $-20^{\circ} \mathrm{C}$ for $30 \mathrm{~min}$. Cells were permeabilized with $0.5 \%$ Triton X-100 in PBS for 5 min. After washing with PBS, the cultures were exposed to $10 \%$ goat serum for $10 \mathrm{~min}$, then to a 1:100 dilution in PBS of rabbit anti-chicken glutamine synthetase (a gift from Paul Linser) or control rabbit serum. After washing, the cultures were incubated with biotinylated goat anti-rabbit IgG (Vector) for $1 \mathrm{~h}$, washed and then exposed for $45 \mathrm{~min}$ to an avidin and biotinylated horseradish peroxidase complex. The cultures were developed in diaminobenzidine.

\section{RESULTS}

\section{Mitogenic response of retinal glia to glutamate}

Fig. 3 shows the effect of various concentrations of glutamate on the proliferation of human retinal glial cells in culture. A concentration-dependent increase in the number of retinal glial cells occurred under serum-free conditions. The increases in cell number at concentrations $>100 \mu \mathrm{M}$ were significant $(P<0.05$, Student's $t$-test). The half-maximally effective concentration of glutamate was $280 \mu \mathrm{M}$. A maximal stimulatory effect occurred with $1 \mathrm{mM}$ glutamate. Concentrations of glutamate greater than $1 \mathrm{mM}$ were toxic to the glial cells.

In addition to assaying cell number, the effect of glutamate on the corporation of bromodeoxyuridine (BrdU) into the nuclei of the glial cells was deter- mined. BrdU, an analog of the nucleotide thymidine, is incorporated into replicating DNA and can be detected by immunocytochemistry using an anti-BrdU monoclonal antibody. In five experiments, cultures of human retinal glial cells were exposed for two days in a serum-free medium (see Materials and Methods) supplemented with $10 \mu \mathrm{M} \mathrm{BrdU}$ and with or without 1 $\mathrm{mM}$ glutamate. Exposure to glutamate was associated with a significantly ( $P<0.001$, Student's $t$-test) higher percent of nuclei that were immunoreactive for BrdU. Specifically, immunocytochemistry revealed that $22 \%$

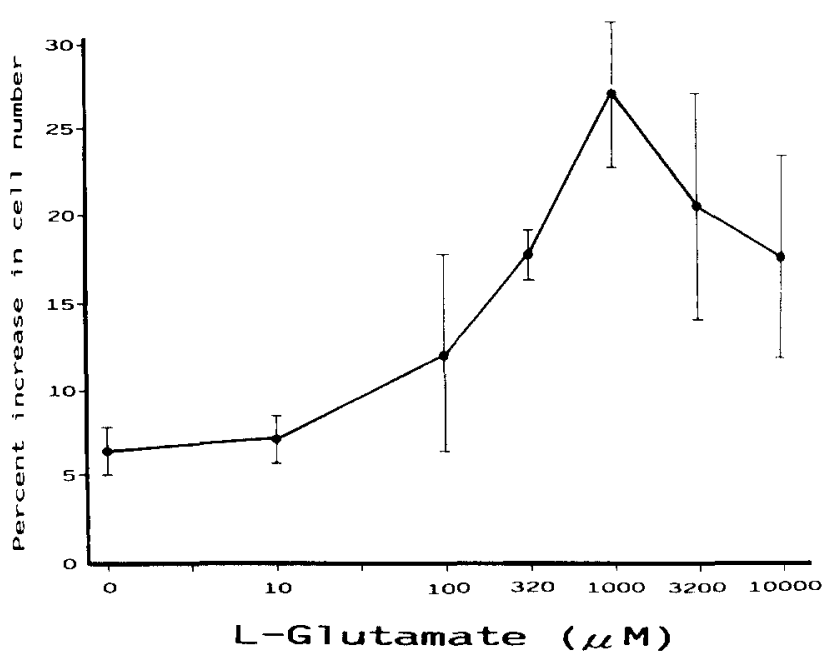

Fig. 3. A dose-response curve for the effect of glutamate on the proliferation of human retinal glial cells in culture. The cells were exposed to medium B plus added glutamate for 2 days (see Materials and Methods). The horizontal axis shows the amount of glutamate added to medium B. Each value represents the mean ( \pm S.D.) of at least three experiments. 
$(S . D .=5)$ of the glial cells in the control plates had nuclei positive for BrdU, while $68 \%($ S.D. $=5)$ of the nuclei in the glutamate-treated group stained positively. These experiments demonstrated that glutamate is a mitogen for the human retinal glial cells in our culture system.

The effect of the duration of exposure to glutamate on retinal glial cell proliferation was also assessed. This was of interest, since cells often require a number of hours of exposure to mitogens in order for proliferation to occur ${ }^{9}$. In Fig. 4, glial cultures were exposed to a serum-free medium supplemented with $1 \mathrm{mM}$ glutamate. At various times, some cultures were switched to medium B without added glutamate. All cultures were assayed for a change in cell number at $48 \mathrm{~h}$. Exposure to an elevated concentration of glutamate for $3 \mathrm{~h}$ or less did not significantly $(P>0.2$, Student's $t$-test) affect cell proliferation. However, at least $4 \mathrm{~h}$ of exposure did significantly increase $(P<0.05$, Student's $t$ test) the proliferation of retinal glial cells. Thus, a period of several hours of exposure to elevated glutamate concentrations is required to induce mitogenesis in these cells under the conditions used here.

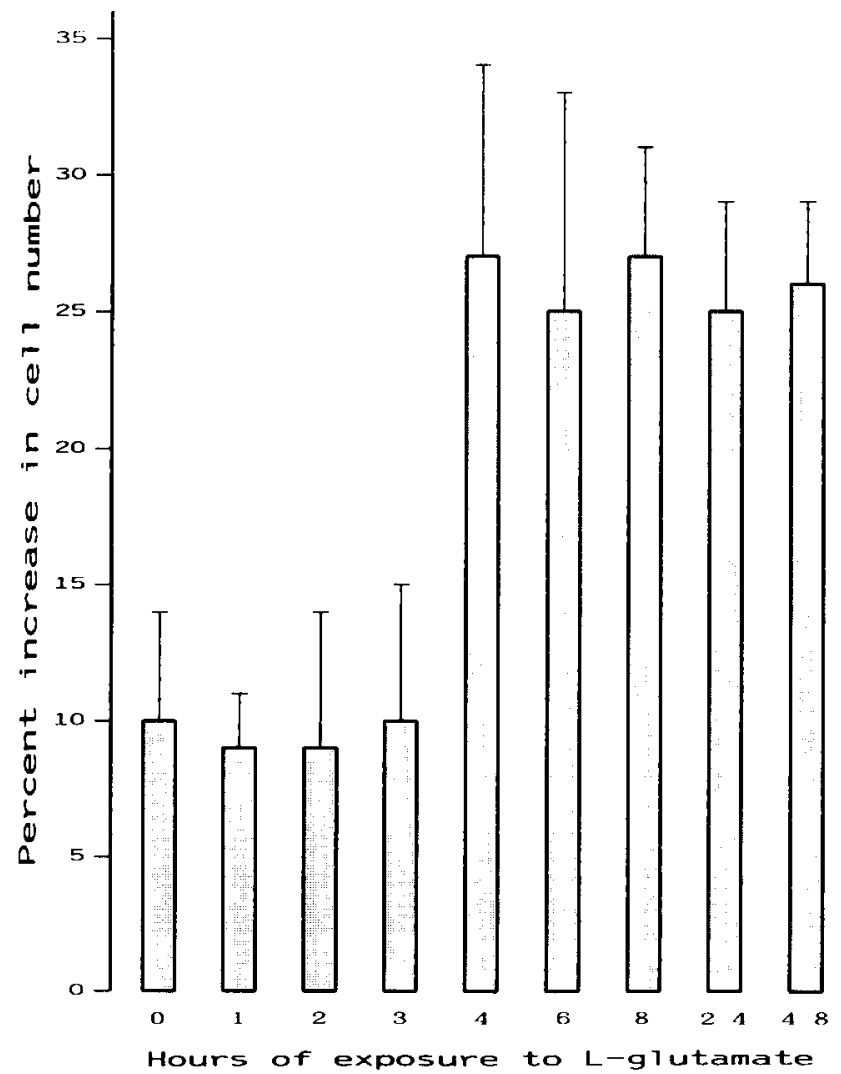

Fig. 4. The effect of the duration of exposure to glutamate on the proliferation of retinal glial cells. Cultures were exposed to medium B supplemented with $1 \mathrm{mM}$ glutamate for various time periods. The proliferation assay was completed 2 days after the onset of the experiment (see Materials and Methods). Each value represents the mean $( \pm$ S.D.) of at least three experiments.
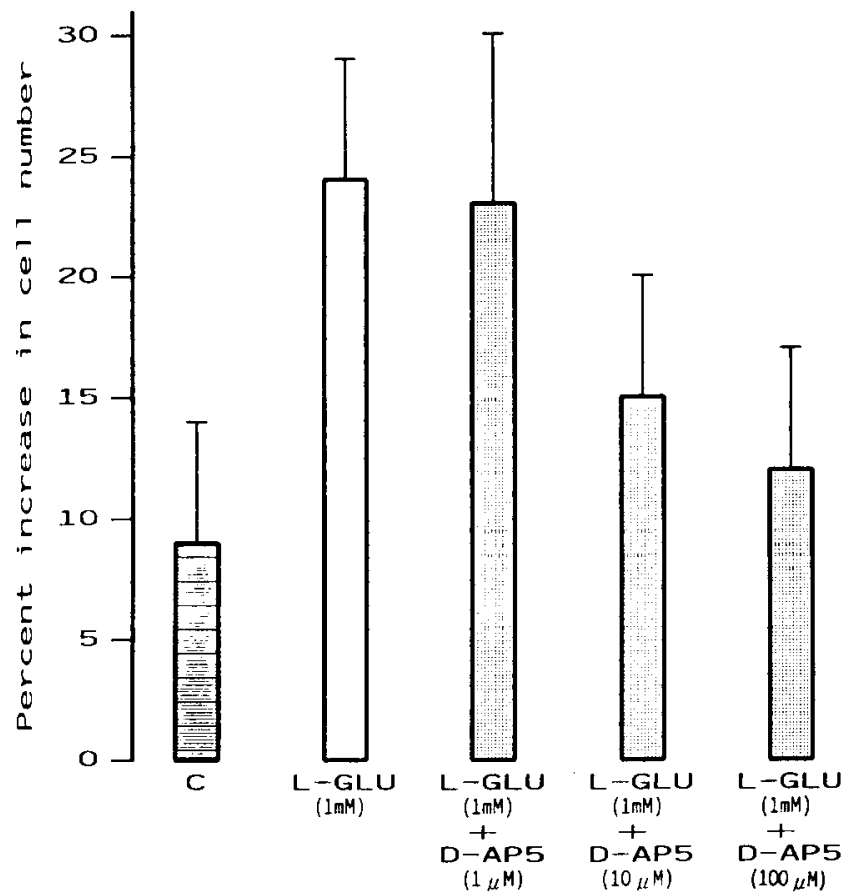

Fig. 5. The effect of D-2-amino-5-phosphonovalerate (D-AP5) on the glutamate-induced proliferation of retinal glial cells. Control cultures (C) were incubated in medium B for $6 \mathrm{~h}$. Other cultures were exposed to medium B supplemented with $1 \mathrm{mM}$ glutamate (L-GLU) plus various concentrations of D-AP5 for $6 \mathrm{~h}$. The proliferation assay was completed 2 days after the onset of the experiment (see Materials and Methods). Each value represents the mean ( \pm S.D.) of at least three experiments.

\section{Pharmacology of the mitogenic effect of glutamate}

With the finding that glutamate is a glial mitogen, it was of interest to study the mechanism by which glutamate-exposure stimulates proliferation. An initial question was what subtype of glutamate receptor is involved in this response. To address this question, the effects on glutamate-induced proliferation of D-2-amino-5phosphonovalerate (D-AP5, a competitive NMDA antagonist), MK-801 (a non-competitive NMDA antagonist) and CNQX (a blocker of non-NMDA glutamate receptors) were assessed (Figs. 5-7). D-AP5 (Fig. 5) and MK-801 (Fig. 6) inhibited significantly $(P<0.005$, Student's $t$-test, at $100 \mu \mathrm{M}$ and $1 \mu \mathrm{M}$ concentrations, respectively) the proliferative effect of glutamate. In contrast to the NMDA-antagonists, $20 \mu \mathrm{M}$ CNQX did not affect $(P>0.2$, Student's $t$-test $)$ the mitogenic response of the glial cells to glutamate (Fig. 7). These pharmacological experiments point to a role for the NMDA subtype of glutamate receptor in mediating the proliferative response of retinal glial cells to glutamate.

Consistent with a role for NMDA receptors, Fig. 8 shows that NMDA can induce the proliferation of human retinal glial cells in culture. A concentrationdependent proliferation of retinal glial cells was observed. The half-maximally effective concentration of NMDA was approximately $48 \mu \mathrm{M}$. To independently 
assess a mitogenic effect of NHDA, the incorporation of $\mathrm{BrdU}$ into the nuclei of glial cells was also determined using immunocytochemistry. After a two-day exposure to $500 \mu \mathrm{M}$ NMDA, $74 \%$ (S.D. $=9, n=5$ ) of the glial cells had nuclei positive for BrdU while $22 \%$ (S.D. $=5, n=5$ ) of the glial cells in the control plates were immunoreactive. These were significantly different $(P<0.001$, Student's $t$-test). Both cell counting and BrdU labeling experiments indicate that NMDA is mitogenic for human retinal glial cells in culture.

Other glutamate agonists were also tested for their effects on glial proliferation. We found that kainate $(100 \mu \mathrm{M})$ and quisqualate $(50 \mu \mathrm{M})$ induced proliferative responses (Fig. 9). We then asked whether kainate or quisqualate acted at non-NMDA or NMDA receptors to stimulate proliferation in our glial cell cultures. Fig. 8 shows that the proliferative responses induced by kainate or quisqualate were blocked significantly $(P<$ 0.01 ) by $1 \mu \mathrm{M}$ MK-801 (a specific antagonist of the NMDA receptor channel) and not affected by $20 \mu \mathrm{M}$ CNQX (an antagonist of non-NMDA receptors). These findings indicate that the kainate- and quisqualate-in-

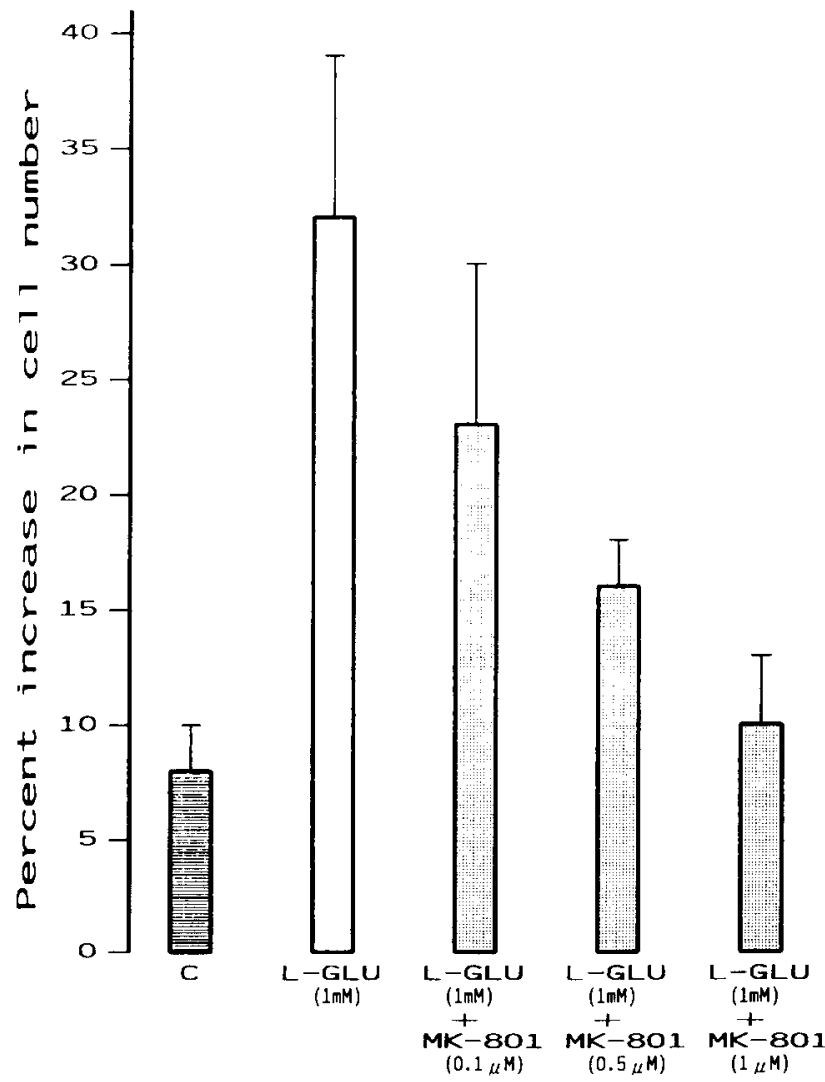

Fig. 6. The effect of MK-801 on the glutamate-induced proliferation of retinal glial cells. Control cultures $(C)$ were incubated in medium $\mathrm{B}$ for $6 \mathrm{~h}$. Other cultures were exposed to medium B and supplemented with $1 \mathrm{mM}$ glutamate (L-GLU) plus various concentrations MK- 801 for $6 \mathrm{~h}$. The proliferation assay was completed at 2 days. Each value represents the mean $( \pm S . D$.) of at least three experiments.

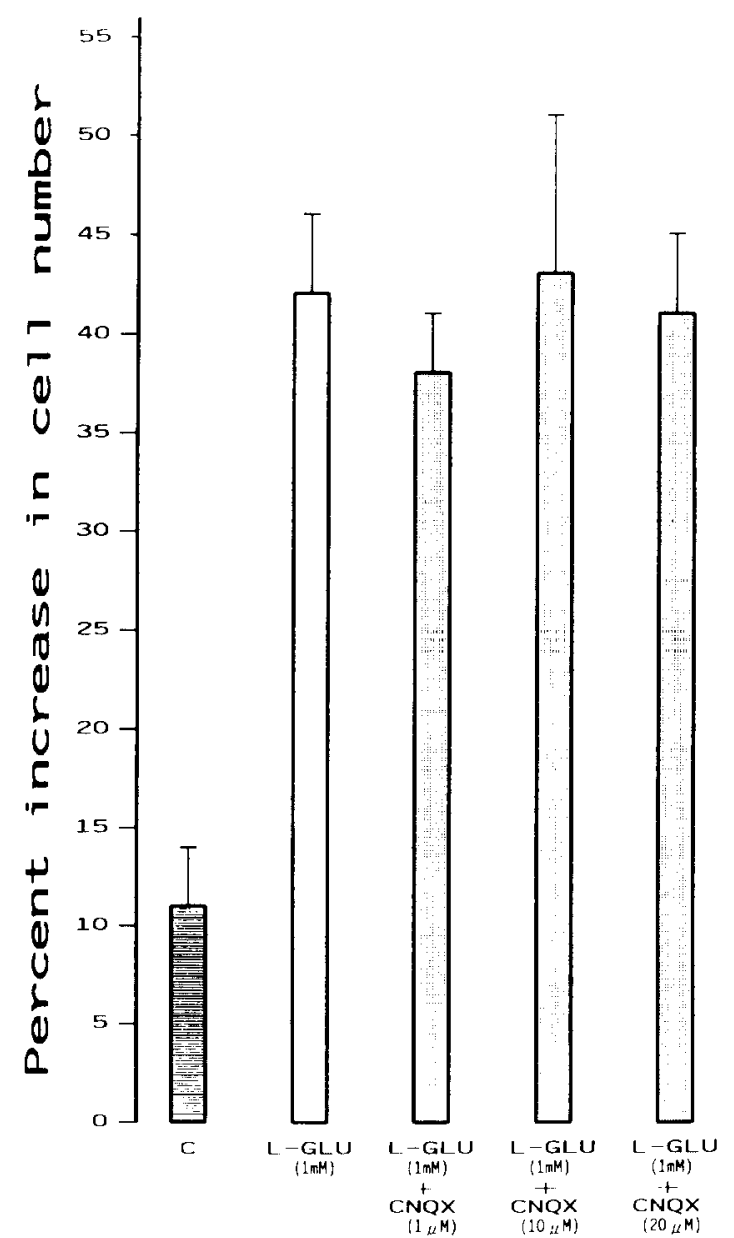

Fig. 7. The effect of CNQX on the glutamate-induced proliferation of retinal glial cells. Control cultures $(C)$ were incubated in medium $\mathrm{B}$ for $6 \mathrm{~h}$. Other cultures were exposed to medium B supplemented with $1 \mathrm{mM}$ glutamate ( $\mathrm{L}-\mathrm{GLU}$ ) plus various concentrations of CNQX for $6 \mathrm{~h}$. The proliferation assay was completed at 2 days. Each value represents the mean $( \pm$ S.D.) of at least four experiments. Medium $B$ contains $250 \mu \mathrm{M}$ glycine.

duced mitogenic effects observed in this study occurred by activation of NMDA receptors.

To obtain further evidence supporting a role for NMDA channels in mediating a mitogenic response, the effect of extracellular magnesium on NMDA-induced proliferation was assessed. The effect of magnesium was of interest, since this divalent cation blocks NMDA, but not non-NMDA, channels ${ }^{3}$. Table II shows that raising the concentration of magnesium in the medium to $10 \mathrm{mM}$ significantly $(P<0.01$, Student's $t$-test) inhibited the proliferative effect of $500 \mu \mathrm{M}$ NMDA.

A requirement of the glial NMDA receptor channels for glycine was not systematically assessed. Although the media used in the experiments summarized in Table II did not contain added glycine (Table I), it is probable that the glial cells in culture release this amino acid into the extracellular space. Future experi- 


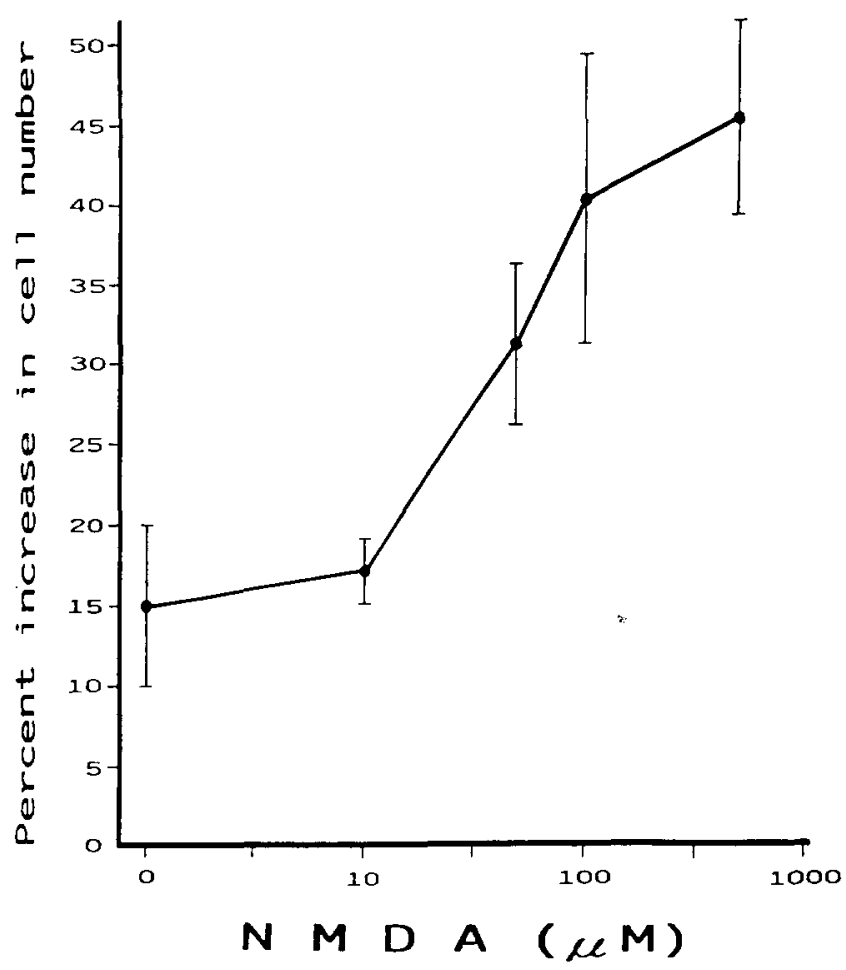

Fig. 8. The dose-response curve for the effect of NMDA on the proliferation of human retinal glial cells. The cells were exposed to $500 \mu \mathrm{M}$ NMDA in medium B for $6 \mathrm{~h}$. The proliferation assay was completed at 2 days. Each value represents the mean ( \pm S.D.) of at least three experiments. Increases in cell number with at least $50 \mu \mathrm{M}$ NMDA were significant $(P<0.01$, Student's $t$-test $)$. At concentrations of at least $1 \mathrm{mM}$ NMDA, toxic effects on the retinal glial cells were sometimes observed.

ments are needed to clarify the effects of glycine and other modulators on NMDA receptor channels in glia.

Manipulation of the ionic composition of the medium helped to examine the possible roles of sodium and calcium in mediating the mitogenic response of retinal glial cells to NMDA (Table II). It is known from studies of other cells ${ }^{3}$ that sodium and calcium can enter a cell via NMDA channels. As shown in Table II, a nominally sodium-free medium did not significantly ( $P=0.21$, Student's $t$-test) affect the induction of proliferation by $500 \mu \mathrm{M}$ NMDA. In contrast, a low cal-

\section{TABLE I}

Composition of medium $C$ and its variations used for the experiments presented in Table II

\begin{tabular}{lcccc}
\hline & $\begin{array}{l}\text { Medium } \\
\left(1 \mathrm{mM} \mathrm{Mg}{ }^{2+}\right)\end{array}$ & $\begin{array}{l}10 \mathrm{mM} \\
\mathrm{Mg}^{2+}\end{array}$ & $\begin{array}{l}\mathrm{Na}^{+} \\
\text {free }\end{array}$ & $\begin{array}{l}\mathrm{Ca}^{2+} \\
\text { free }\end{array}$ \\
\hline $\mathrm{NaCl}$ & 137 & 123.5 & 0 & 139.7 \\
$\mathrm{KCl}$ & 5.4 & 5.4 & 5.4 & 5.4 \\
$\mathrm{MgCl}_{2}$ & 1 & 10 & 1 & 1 \\
$\mathrm{CaCl}_{2}$ & 1.8 & 1.8 & 1.8 & 0 \\
$\mathrm{Glucose}_{\mathrm{Na} H E P E S}$ & 10 & 10 & 10 & 10 \\
$\mathrm{Choline-C1}$ & 10 & 10 & 10 & 10 \\
EGTA & & & 137 & 1 \\
\hline
\end{tabular}

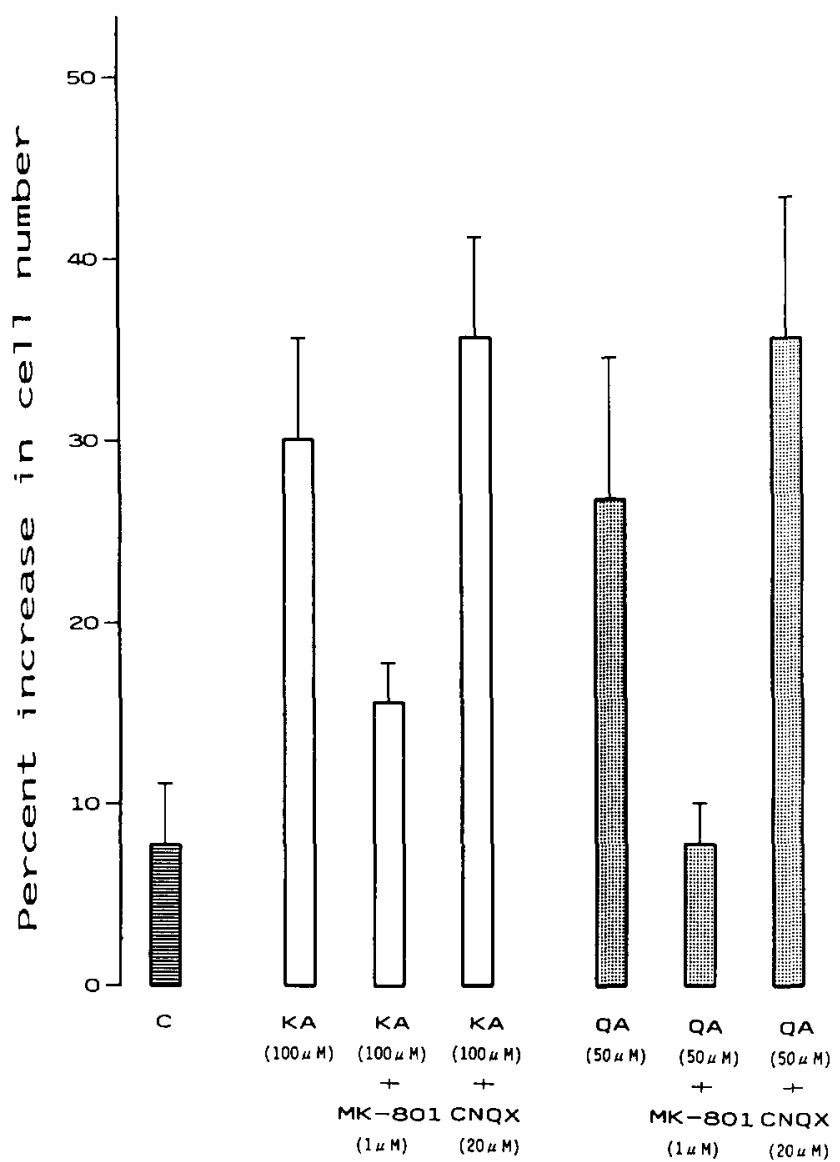

Fig. 9. Pharmacological evaluation of the effects of kainate (KA) and quisqualate (QA) on retinal glial cell proliferation. Cells were exposed to control (C) or experimental conditions for $6 \mathrm{~h}$. The proliferation assay was completed at 2 days. Each value represents the mean $( \pm$ S.D.) of at least three experiments. MK-801 $(1 \mu \mathrm{M})$ significantly ( $P=0.006$, Student's $t$-test) inhibited the proliferative effects of 100 $\mu \mathrm{M}$ kainate and $50 \mu \mathrm{M}$ quisqualate $(P<0.001$, Student's $t$-test $)$. CNQX $(20 \mu \mathrm{M})$ did not inhibit the effect of $100 \mu \mathrm{M}$ kainate or 50 $\mu \mathrm{M}$ quisqualate. Apparent increases in cell number in CNQX-treated cultures when compared with cultures exposed only to kainate or quisqualate were not significant $(P>0.07$, Student's $t$-test).

cium concentration in the medium prevented the mitogenic effect of $500 \mu \mathrm{M}$ NMDA (Table II). These findings support the possibility that an influx of cal-

\section{TABLE II}

Effect of extracellular concentrations of magnesium, sodium and calcium on the NMDA-induced proliferation of human retinal glial cells in culture

Cells were exposed to either medium $C$, which contained $1 \mathrm{mM}$ $\mathrm{Mg}^{2+}$, or its variations (see Table I) without or with $500 \mu \mathrm{M}$ NMDA. After $4.5 \mathrm{~h}$, the cultures were switched to medium B. The cell proliferation assay was completed 2 days later. Each value represents the mean ( \pm S.D.) of at least four experiments.

\begin{tabular}{lc}
\hline Conditions & $\begin{array}{c}\text { Increase in cell } \\
\text { number }(\%)\end{array}$ \\
\hline No NMDA, $1 \mathrm{mM} \mathrm{Mg}^{2+}$ & $9 \pm 4$ \\
NMDA, $1 \mathrm{mM} \mathrm{Mg}^{2+}$ & $28 \pm 7$ \\
NMDA, $10 \mathrm{mM} \mathrm{Ng}^{2+}$ & $8 \pm 4$ \\
NMDA, low Na & $23 \pm 3$ \\
NMDA, low Ca & $6 \pm 6$ \\
\hline
\end{tabular}


cium plays a role in the proliferative response of human retinal glial cells to NMDA.

\section{DISCUSSION}

The results show that glutamate, via activation of NMDA receptors, stimulates the proliferation of human retinal glial cells in culture. Our evidence for a role of NMDA receptors is based on a number of findings. Importantly, the glutamate-induced proliferation is blocked by D-AP5 and MK-801 (antagonists of NMDA receptors), but not by CNQX (an antagonist of non-NMDA glutamate receptors). Also, NMDA itself stimulates proliferation of retinal glial cells. Furthermore, the effect of NMDA on cell proliferation is sensitive to elevated magnesium levels and is dependent on extracellular calcium. These characteristics are consistent with an activation of NMDA receptor channels ${ }^{3}$.

This is the first report showing evidence for the presence of functional NMDA receptors on glial cells. Consistent with the concept that at least some glia have NMDA receptors are recent studies using antibodies to cDNA-derived peptides of an NMDA receptor $^{26}$ or in situ hybridization with riboprobes directed against the NMDAR1 subunit of the receptor ${ }^{15}$. These reports indicate that hippocampal astrocyte ${ }^{26}$ and cerebellar Bergmann glia ${ }^{15}$ express NMDA receptors. In contrast, functional NMDA receptor channels have not been detected in studies of cultured glia from perinatal rodent and avian brains ${ }^{7,10,11}$, Müller glial cells freshly dissociated from the salamander retina ${ }^{12,32}$ and astrocytes on the inner surface of the rabbit retina ${ }^{14}$. Whether a difference in the detection of NMDA receptor channels in glia reflects differences in species, degree of maturation, CNS sites, types of glial cells, enzyme-treatment of cells, in vitro conditions or assay techniques is not known.

It is clear that caution concerning changes in cellular characteristics in culture is needed. However, the culture system used here appears to be a reasonable system in which to study aspects of the pathophysiology of human retinal glial cells. For example, the cells in our cultures are immunoreactive to antibodies for glial fibrillary acidic protein and Müller cells ${ }^{30}$, as are proliferating cells often found in multicellular complexes located on and under the retinal surface or extending into the vitreous in eyes with various retinal diseases ${ }^{13,17,36}$. Yet, despite these similarities, it remains to be demonstrated that the NMDA receptors found in our cultured cells are, in fact, also expressed by retinal glial cells in vivo.

The NMDA receptors on cultured retinal glial cells may differ from those found on neurons. One possible difference may be in the sensitivity of the NMDA channel to blockade by magnesium. Neural NMDA channels at the resting membrane potential are blocked significantly by physiological concentrations of magnesium $^{3}$. In contrast, the effectiveness of NMDA on glial proliferation in the presence of 1 to $1.5 \mathrm{mM} \mathrm{Mg}^{2+}$ (Fig. 8 and Table II) suggests a relatively low sensitivity to the blocking action of this divalent cation. Perhaps retinal glia express heteromeric NMDA receptor channels which have a low sensitivity to magnesium-block as has been found in recent molecular studies ${ }^{18,22,23}$. Future electrophysiological recordings are needed to characterize the magnesium sensitivity of the NMDA channels in human retinal glial cells.

Another possible difference between glial and neuronal NMDA receptors may be the effectiveness of various ligands. For example, we found that $100 \mu \mathrm{M}$ kainate was only slightly less effective than $100 \mu \mathrm{M}$ NMDA at inducing glia proliferation (Figs. 8 and 9). The proliferation induced by kainate involved the activation of NMDA receptors, since MK-801 and not CNQX, was inhibitory (Fig. 9). This effectiveness of kainate at glial NMDA receptors appears to be greater than its effectiveness at the NMDAR1 subtype of NMDA receptor channel ${ }^{24}$. However, the binding of kinate to other subtypes of NMDA receptor channels has not been reported. Our finding that kainate activates NMDA receptors on retinal glial cells is consistent with in vivo experiments in which Sahel et al. ${ }^{31}$ found that intravitreal injection of kainate induced mitoses in retinal Müller cells by a mechanism inhibited by ketamine, a non-competitive NMDA-blocker. We also observed that a relatively high concentration of glutamate (Fig. 3) was needed to induce proliferation. Rather than indicating a low sensitivity of the glial NMDA receptor to glutamate, we speculate that an active uptake carrier in the glia lowers the glutamate concentration during the 4 -h period required to induce a mitogenic response. Use of the patch clamp technique to study the effects of glutamate and its agonists on NMDA receptor channels of retinal glial cells should help clarify these issues. Also, subsequent studies are needed to characterize the effects on glial NMDA receptor channels of glycine and other modulators.

The mechanism by which activation of NMDA receptors on retinal glial cells induces a mitogenic response is uncertain. Our experiments indicate that an influx of calcium is required for the NMDA-induced proliferation. However, the subsequent pathway by which the NMDA receptor signal is processed is not known. In brain cells, activation of NMDA receptors 
can be associated with phosphorylation of tyrosine residues in a protein kinase $^{5}$ and stimulation of the inositol phosphate/diacylglycerol second messenger pathway ${ }^{33}$. Whether these pathways play a role in the proliferative response to NMDA studied here remains to be determined.

Glutamate is not the only neurotransmitter that can be a glial mitogen. The acetylcholine analog, carbachol, stimulates DNA synthesis in cultured astrocytes from the perinatal rodent brain ${ }^{4}$. However, this is an age-dependent phenomenon with minimal stimulation of DNA synthesis in glia from rats older than 2 weeks postnatal. We assayed for the mitogenic effect of carbachol in our cultures of glia from the adult retina and did not detect any effect (unpublished observations). The study presented here is the first report of a neurotransmitter being mitogenic for glia from the adult nervous system.

What could be the significance of NMDA receptors on retinal glial cells? Since most retinal neurons are glutamatergic $^{21}$, NMDA receptors are likely to be activated in the retina. Thus, glutamate may act as a neuron-to-glial signal as well as a transmitter for communication between retinal neurons. However, the physiological function of a short-term activation of NMDA receptors on retinal glia is unknown. Perhaps an influx of calcium via NMDA channels may activate the calcium-sensitive potassium channels that are present in these cells ${ }^{27}$ and, thereby facilitate in the regulation of potassium homeostasis in the retina.

Another possible function of glial NMDA receptors in the retina may be to mediate a cellular response to pathophysiological conditions, such as retinal ischemia, trauma or detachment, in which neurons are injured. Under these conditions there may be a prolonged elevation of extracellular glutamate released by depolarized neurons. Our proliferation assays demonstrate that the exposure of retinal glial cells to glutamate for several hours elicits a mitogenic response via activation of NMDA receptors. A glutamate-induced proliferation of glia may be a successful adaptive response of the retina resulting in the creation of more glial cells that would reduce potentially neurotoxic levels of glutamate. On the other hand, an excessive proliferation of glial cells often is a significant factor in compromising neural function with disease or injury. It remains to be determined whether drugs which block NMDA receptors may be useful in limiting detrimental effects of glial proliferation in the retina.

Acknowledgements. The authors thank Dr. Paul Linser for providing antibodies to glutamine synthetase. This work was supported in part by Grants EY 06931 and EY 07003 from the National Eye
Institute, NIH, Bethesda, MD. DGP is a Research to Prevent Blindness Senior Scientific Investigator.

\section{REFERENCES}

1 Anderson, D.H., Guerin C.J., Erickson, P.A., Stern, W.H., and Fisher, S.K., Morphological recovery in the reattached retina, Invest. Ophthalmol. Vis. Sci., 27 (1986) 168-183.

2 Aotaki-Keen, A.E., Harvey, A.K., De Juan, E. and Hjelmeland, L.M., Primary culture of human retinal glia, Invest. Ophthalmol. Vis. Sci., 32 (1991) 1733-1738.

3 Ascher, P. and Nowak, L., Electrophysiological studies of NMDA receptors, Trends Neurosci., 10 (1987) 284-288.

4 Ashkenazi, A., Ramachandran, J. and Capon, D.J., Acetylcholine analogue stimulates DNA synthesis in brain-derived cells via specific muscarine receptor subtypes, Nature, 340 (1989) 146-150.

5 Bading, $H$. and Greenberg, M.E., Stimulation of protein tyrosine phosphorylation by NMDA receptor activation, Science, 253 (1991) 912-914.

6 Barres, B.A., New roles for glia, J. Neurasci., 11 (1991) 3685-3694.

7 Barres, B.A., Chun, L.L.Y. and Corey, D.P., Ion channels in vertebrate glia, Annu. Rev. Neurosci., 13 (1990) 441-474.

8 Benveniste, H., Drejer, J., Schousboe, A. and Diemer, N.H., Elevation of the extracellular concentrations of glutamate and aspartate in rat hippocampus during transient cerebral ischemia monitored by intracellular microdialysis, J. Neurochem., 43 (1984) $1369-1374$.

9 Berridge, M.J., Brown K.D., Irvine, R.F. and Heslop, J.P., Phosphoinositides and cell proliferation, J. Cell Sci. Suppl., 3 (1985) 187-198.

10 Bevan, S., Ion channels and neurotransmitter receptors in glia, Semin. Neurosci., 2 (1990) 467-481.

11 Von Blankenfeld, G. and Kettenmann, H., Glutamate and GABA receptors in vertebrate glial cells, Mol. Neurobiol, 5 (1992) 31-43.

$12 \mathrm{Brew}, \mathrm{H}$. and Attwell, D., Electrogenic glutamate uptake is a major current carrier in the membranes of axolotl retinal glial cells, Nature, 327 (1987) 707-709.

13 Chan, C.-C., Palestine, A.J., Kuwabara, T. and Nussenblatt, R.B., Immunopathologic study of Vogt-Koyanagi-Harada syndrome, Am. J. Ophthalmol., 105 (1988) 607-611.

14 Clark, B. and Mobbs, P., Transmitter-operated channels in rabbit retinal astrocytes studied in situ by whole-cell patch clamping, $J$. Neurosci., 12 (1992) 664-673.

15 Fan, D., Johnson, A.B., Kessler, J.A. and Zukin, R.S., Glutamate receptor subtypes are differentially expressed in cultured hippocampal astrocytes, Soc. Neurosci. Abstr., 18 (1992) 89.

16 Hagberg, H., Lehmann, A., Sandberg, M., Nystrom, B., Jacobson, I. and Hamberger A., Ischemia-induced shift of inhibitory and excitatory acids from intra- to extracellular compartments, $J$. Cereb. Blood Flow Metabol., 5 (1985) 314-419.

17 Hiscott, P.S., Grierson, I., Trombretta, C.J., Rehi, A.N.S., Marshall, J. and McLean, D., Retinal and epiretinal glia - an immunohistochemical study, Br. J. Ophthalmol., 68 (1984) 698707.

18 Kutsuwada, T., Kashiwabuchi, N., Mori, H., Sakimura, K., Kushiya, E., Araki, K., Meguro, H., Masaki, H., Kumanishi, T., Arakawa, M. and Mishina, M., Molecular diversity of the NMDA receptor channel, Nature, 358 (1992) 36-41.

19 Lewis, G.P., Erickson, P.A., Kaska, D.D. and Fisher, S.K., An immunocytochemical comparison of Müller cells and astrocytes in the cat retina, Exp. Eye Res., 47 (1988) 839-953.

20 Malhotra, S.K., Shnitka, T.K. and Elbrink, J., Reactive astrocytes - a review, Cytobios, 61 (1990) 133-160.

21 Massey, S.C., Cell types using glutamate as a neurotransmitter in the vertebrate retina, Prog. Retinal Res., 9 (1990) 399-425.

22 Monyer, H., Sprengel, R., Schoepfer, R., Herb, A., Higuchi, M., Lomeli, H., Burnashev, N., Sakmann, B. and Seeburg, P.H., Heteromeric NMDA receptors: molecular and functional distinction of subtypes, Science, 256 (1992) 1217-1221.

23 Mori, H. Masaki, H., Yamakura, T. and Mishina, M., Identification by mutagenesis of a $\mathrm{Mg}^{2+}$-block site of the NMDA receptor 
channel, Nature, 358 (1992) 673-675.

24 Moriyoshi, K., Masayuki, M., Ishii, T., Shigemoto, R., Mizuno, N. and Nakanishi, S., Molecular cloning and characterization of the rat NMDA receptor, Nature, 354 (1991) 31-37.

25 Oka, M.S., Frederick, J.M., Landers, R.A. and Bridges, C.D.B., Adult human retinal cells in culture: identification of cell types and expression of differential properties, Exp. Cell Res., 159 (1985) 127-134

26 Pratt, G.D., Fritschy, J.-M. and Mohler, H., Non-neuronal location of GABA and NMDA receptors in early postnatal rat cerebellum, Soc. Neurosci. Abstr., 18 (1992) 422.

27 Puro, D.G., Stretch-activated channels in human retinal Müller cells, Glia, 4 (1991) 456-460.

28 Puro, D.G., Calcium channels of human retinal glial cells. In T. Narahashi (Ed.), Methods of Neuroscience, Vol. 14, Academic Press, Orlando, FL, in press.

29 Puro, D.G. and Mano, T., Modulation of calcium channels in human retinal glial cells by basic fibroblast growth factor: a possible role in retinal pathobiology, J. Neurosci., 11 (1991) 1873-1880.

30 Puro, D.G., Mano, T., Chan, C.-C., Fukuda, M. and Shimada, H., Thrombin stimulates the proliferation of human retinal glial cells, Graefe's Arch. Clin. Exp. Ophthalmol., 228 (1990) 169-173.
31 Sahel J.A., Albert D.M., Lessell, S., Adler, H., McGee, T.L. and Konrad-Rastegar, J., Mitogenic effects of excitatory amino acids in the adult rat retina, Exp. Eye Res., 53 (1991) 657-664.

32 Schwartz, E.A. and Tachibana, M., Electrophysiology of glutamate and sodium co-transport in a glial cell of the salamander retina, J. Physiol, 426 (1990) 43-80.

33 Sladeczek, F., Recaseno, M. and Bockaert, J., A new mechanism for glutamate receptor action: phosphoinositide hydrolysis, Trends Neurosci., 11 (1988) 545-549.

34 Stefanson, E., Wilson, C.A., Schoen, T. and Kuwabara, T., Experimental ischemia induces cell mitoses in the adult rat retina, Invest. Ophthalmol. Vis. Sci., 29 (1987) 1050-1055.

35 Uchihori, Y. and Puro, D.G., Mitogenic and chemotactic effects of platelet-derived growth factor on human retinal glial cells, Invest. Ophthalmol. Vis. Sci., 32 (1991) 2689-2695.

36 Vinores, S.A., Campachiaro, P.A. and Conway, B.P., Ultrastructural and electron-immunocytochemical characterization of cells in epiretinal membranes, Invest. Ophthalmol. Vis. Sci., 31 (1990) $14-27$.

37 Yong, V.W., Kim, S.U. and Pleasure, D.E., Growth factors for fetal and adult human astrocytes in culture, Brain Res., 444 (1988) 59-66. 